\title{
One-and-a-half syndrome secondary to transorbital penetrating injury
}

Tess Fitzpatrick, MD, Margaret Moores, MD, Simon Thebault, MD, and Hyman Rabinovitch, MD

Neurology ${ }^{\odot}$ 2018;90:91-92. doi:10.1212/WNL.0000000000004807

Figure 1 CT head
Correspondence

Dr. Fitzpatrick

tfitzpatrick@qmed.ca

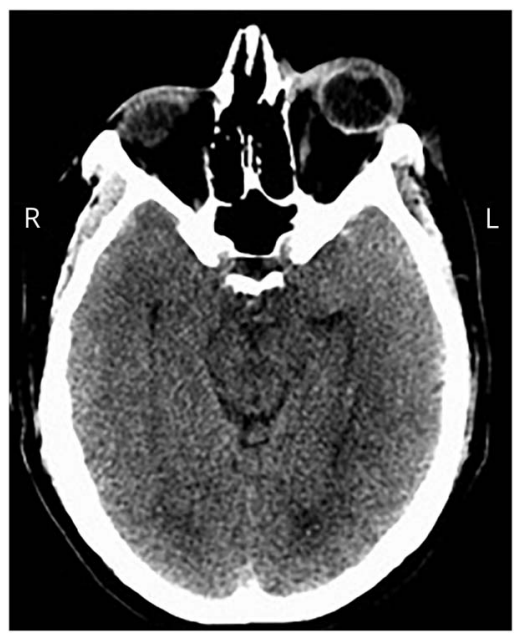

Noncontrast CT head shows left eye proptosis and hyperdense stranding in the retrobulbar space consistent with hemorrhage.

A 46-year-old woman sustained a penetrating left eye (OS) injury after tripping and falling onto a motorcycle antenna. She removed the antenna immediately and presented to the emergency room complaining of diplopia. Examination demonstrated proptosis and subconjunctival hemorrhage OS. Her diplopia was initially attributed to mechanical restriction OS secondary to retrobulbar hemorrhage visualized on CT scan (figure 1). Careful examination, however, revealed left conjugate horizontal gaze palsy and left internuclear ophthalmoplegia. This was consistent with one-and-a-half syndrome from left pons penetrating trauma, confirmed on MRI (figure 2). Two months later, her condition had improved, but she continued to demonstrate abduction paresis OS.

\section{Author contributions}

Tess Fitzpatrick: primary manuscript author. Margaret Moores: manuscript author and prepared submission. Simon Thebault: manuscript author and compiled figures. Hyman Rabinovitch: edited for intellectual content.

\section{Study funding}

No targeted funding reported.

\section{Disclosure}

The authors report no disclosures relevant to the manuscript. Go to Neurology.org/ $\mathrm{N}$ for full disclosures. 

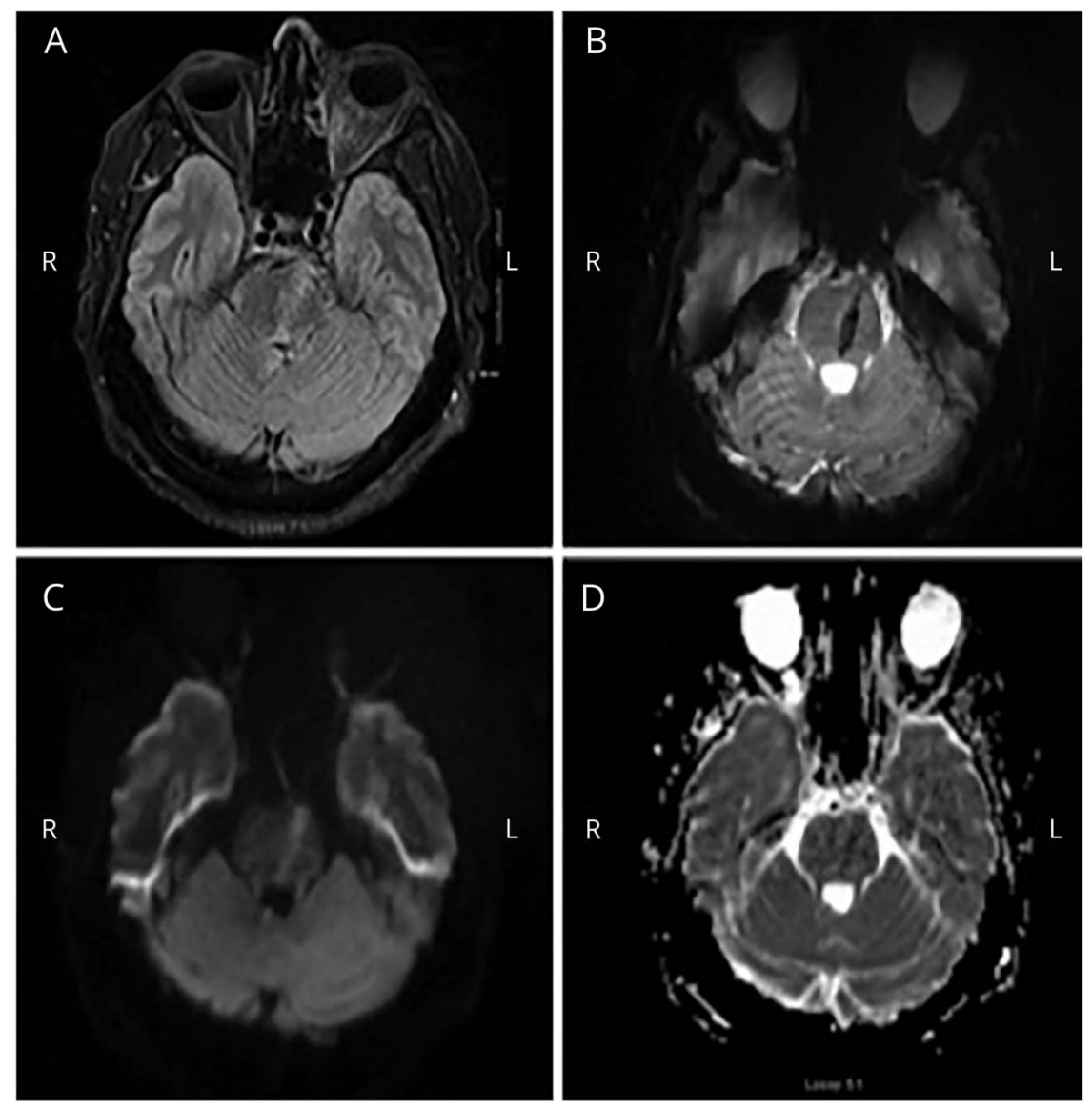

MRI shows linear signal abnormality extending from left pons to right superior cerebellar hemisphere on (A) fluid-attenuated inversion recovery, (B) echoplanar imaging, (C) diffusion-weighted imaging, and (D) apparent diffusion coefficient images. This indicates posttraumatic hemorrhage along antenna tract involving the medial longitudinal fasciculus and sixth cranial nerve nucleus.

\section{Neurology.org/N Offers Important Information to Patients and Their Families}

The Neurology ${ }^{\circledR}$ Patient Page provides:

- A critical review of ground-breaking discoveries in neurologic research that are written especially for patients and their families

- Up-to-date patient information about many neurologic diseases

- Links to additional information resources for neurologic patients

All Neurology Patient Page articles can be easily downloaded and printed, and may be reproduced to distribute for educational purposes. Click on the 'Patients' link on the home page (Neurology.org/N) for a complete index of Patient Pages. 


\section{Neurology}

\section{One-and-a-half syndrome secondary to transorbital penetrating injury Tess Fitzpatrick, Margaret Moores, Simon Thebault, et al. Neurology 2018;90;91-92 \\ DOI 10.1212/WNL.0000000000004807}

\section{This information is current as of January 8, 2018}

\section{Updated Information \& Services}

\section{Subspecialty Collections}

Permissions \& Licensing

Reprints including high resolution figures, can be found at: http://n.neurology.org/content/90/2/91.full

This article, along with others on similar topics, appears in the following collection(s):

\section{Clinical neurology examination}

http://n.neurology.org/cgi/collection/clinical_neurology_examination MRI

http://n.neurology.org/cgi/collection/mri

Ocular motility

http://n.neurology.org/cgi/collection/ocular_motility

Orbit

http://n.neurology.org/cgi/collection/orbit

Other cerebrovascular disease/ Stroke

http://n.neurology.org/cgi/collection/other_cerebrovascular_disease_st roke

Information about reproducing this article in parts (figures,tables) or in its entirety can be found online at:

http://www.neurology.org/about/about_the_journal\#permissions

Information about ordering reprints can be found online:

http://n.neurology.org/subscribers/advertise

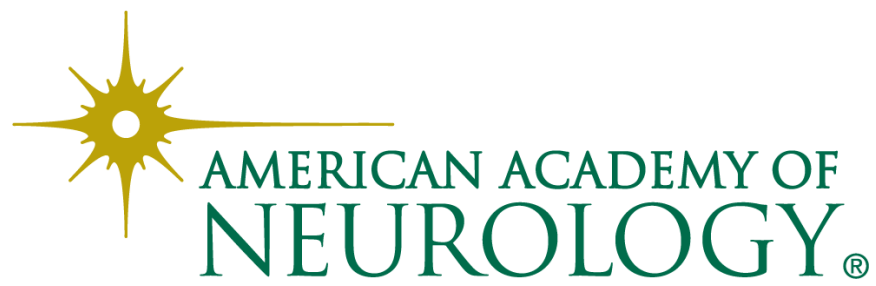

